Alterações cognitivas e do autocuidado em pacientes com insuficiência cardíaca na

\title{
Região Amazônica
}

Cognitive and self-care changes in patients with heart failure in the Amazon Region

Cambios cognitivos y de cuidado personal en pacientes con insuficiencia cardíaca en la Región de la Amazonía

Recebido: 08/04/2020 | Revisado: 15/04/2020 | Aceito: 17/04/2020 | Publicado: 18/04/2020

Adriana de Oliveira Lameira Veríssimo

ORCID: https://orcid.org/0000-0002-3497-7106

Hospital Adventista de Belém, Brazil

E-mail: adylameira@gmail.com

Juniel Pereira Honorato

ORCID: https://orcid.org/0000-0002-7386-8041

Hospital Adventista de Belém, Brazil

E-mail: junielhonorato27@gmail.com

Sílvio Douglas Medeiros Costa

ORCID: https://orcid.org/0000-0003-2938-3845 Hospital Universitário João de Barros Barreto, Brazil

E-mail: douglas_mc20@hotmail.com

João Victor Moura Garcia

ORCID: https://orcid.org/0000-0001-6305-6042

Universidade Federal do Pará, Brazil

E-mail: joaovgarcia98@gmail.com

Isis Jaspe Reis da Silva

ORCID: https://orcid.org/0000-0002-8015-1348

Universidade Federal do Pará, Brazil

E-mail: isisjaspe01@gmail.com

Stanley Soares Xavier

ORCID: https://orcid.org/0000-0002-4040-4144

Universidade do Estado do Pará, Brazil

E-mail: stx.xavier@yahoo.com.br 


\author{
Aline Maria Pereira Cruz Ramos \\ ORCID: https://orcid.org/0000-0001-8812-2923 \\ Universidade Federal do Pará, Brazil \\ E-mail: nurse.alinecruz@gmail.com \\ Milene Gouvêa Tyll \\ ORCID: https://orcid.org/0000-0002-5487-7110 \\ Hospital das Clínicas Gaspar Viana, Brazil \\ E-mail: milenetyl@hotmail.com
}

\title{
Resumo
}

A Insuficiência Cardíaca é caracterizada como a ausência de capacidade de bombeamento sanguíneo realizado pelo coração, sendo esta considerada um problema de saúde pública a nível mundial. Devido a IC, o individuo pode desenvolver aspectos clínicos que impactam na função cognitiva e consequentemente na realização do autocuidado. Diante disso, este estudo teve como objetivo investigar as alterações cognitivas e o autocuidado em pacientes acometidos por IC e comparar com as alterações cognitivas e de autocuidado dos participantes saudáveis. Trata-se de um estudo quantitativo, epidemiológico, transversal do tipo casocontrole, realizado em uma instituição no município de Belém, Pará, Brasil. Foram utilizados para coleta de dados os testes: Avaliação Cognitiva de Montreal, Digit Symbol Substitution Test, European Heart Failure Self-care Behavior Scale (EHFScBS). Os dados foram tabulados em Microsoft Excel 2010 e tratados estatisticamente pelo Epi Info versão 3.5 .2 com nível de significância de $5 \%$ e considerando intervalo de confiança de $95 \%$ em todas as análises. Observou-se que os paciente com IC apresentam autocuidado discretamente melhor em relação aos pacientes sem IC com scores obtidos pelo EHFScBS iguais a 29,7 $\pm 6,9$ e 31,8 $\pm 8,2$, respectivamente. Adicionalmente os pacientes com IC apresentaram prejuízos nos três domínios cognitivos, sendo que as mulheres com IC demonstraram ter maior prejuízo cognitivo em relação aos demais participantes. O presente estudo traz dados para auxiliar a construção de novas abordagens de intervenções da equipe multiprofissional para promover melhor autocuidado e evitar prejuízos cognitivos em pacientes com IC.

Palavras-chave: Insuficiência cardíaca; Autocuidado; Cognição; Epidemiologia.

\section{Abstract}

Heart failure is characterized as the lack of blood pumping capacity performed by the heart, which is considered a public health problem worldwide. Due to HF, the individual can 
develop clinical aspects that impact cognitive function and, consequently, self-care. Therefore, this study aimed to investigate cognitive changes and self-care in patients affected by HF and compare it with the cognitive and self-care changes of healthy participants. This is a quantitative, epidemiological, cross-sectional case-control study carried out at an institution in the city of Belém, Pará, Brazil. The following tests were used for data collection: Montreal Cognitive Assessment, Digit Symbol Substitution Test, European Heart Failure Self-care Behavior Scale (EHFScBS). Data were tabulated in Microsoft Excel 2010 and statistically treated by Epi Info version 3.5 .2 with a 5\% significance level and considering a 95\% confidence interval in all analyzes. It was observed that patients with HF have slightly better self-care compared to patients without HF with scores obtained by EHFScBS equal to $29.7 \pm$ 6.9 and $31.8 \pm 8.2$, respectively. Additionally, patients with HF showed impairments in the three cognitive domains, and women with HF demonstrated greater cognitive impairment compared to the other participants. The present study provides data to help build new approaches to interventions by the multidisciplinary team to promote better self-care and avoid cognitive impairments in patients with HF.

Keywords: Heart failure; Self care; Cognition; Epidemiology.

\section{Resumen}

La insuficiencia cardíaca se caracteriza por la falta de capacidad de bombeo de sangre realizada por el corazón, que se considera un problema de salud pública en todo el mundo. Debido a la insuficiencia cardíaca, el individuo puede desarrollar aspectos clínicos que afectan la función cognitiva y, en consecuencia, el autocuidado. Por lo tanto, este estudio tuvo como objetivo investigar los cambios cognitivos y el autocuidado en pacientes afectados por IC y compararlo con los cambios cognitivos y de autocuidado de los participantes sanos. Este es un estudio cuantitativo, epidemiológico, transversal de casos y controles realizado en una institución en la ciudad de Belém, Pará, Brasil. Se utilizaron las siguientes pruebas para la recopilación de datos: Evaluación Cognitiva de Montreal, Prueba de sustitución de símbolo de dígitos, Escala de comportamiento de autocuidado de insuficiencia cardíaca europea (EHFScBS). Los datos se tabularon en Microsoft Excel 2010 y se trataron estadísticamente con Epi Info versión 3.5.2 con un nivel de significación del 5\% y considerando un intervalo de confianza del $95 \%$ en todos los análisis. Se observó que los pacientes con IC tienen un autocuidado ligeramente mejor en comparación con los pacientes sin IC con puntajes obtenidos por EHFScBS igual a $29.7 \pm 6.9$ y $31.8 \pm 8.2$, respectivamente. Además, los pacientes con insuficiencia cardíaca mostraron deficiencias en los tres dominios cognitivos, y 
las mujeres con insuficiencia cardíaca demostraron un mayor deterioro cognitivo en comparación con los otros participantes. El presente estudio proporciona datos para ayudar a construir nuevos enfoques de las intervenciones del equipo multidisciplinario para promover un mejor autocuidado y evitar el deterioro cognitivo en pacientes con insuficiencia cardíaca.

Palabras clave: Insuficiencia cardíaca; Autocuidado; Cognición; Epidemiología.

\section{Introduction}

Heart failure (HF) is defined as an inability of the heart to pump blood effectively (CCDIC, 2018).This is considered a worldwide public health problem, being the main cause of hospitalization and mortality (Albuquerque et al., 2015; Boisvert, Proulx-Belhumeur, Gonçalve, Francoeur, \& Gallani, 2015). In 2017, there were 27,461 deaths from HF in Brazil, representing $16.7 \%$ of 567,370 hospital admissions in the first half of 2019 alone (Brazil, 2019a; Brazil, 2019b).

HF self-care refers to behavioral actions to maintain health and autonomy in decisionmaking during the worsening symptoms (management of self-care). Several clinical, physical, psychological, situational, and social aspects can affect self-care, requiring individual behavioral changes to deal with the disease and the treatment (Ferreira et al., 2015).

Cognition is considered to have the main influence on self-care maintenance, especially in older adults, resulting in greater adherence to treatment and lower readmissions (Uchmanowicz, Polańska, Mazur \& Froelicher, 2017).

Given the above mentioned issues, the indispensability of conducting an investigation about the cognitive alterations and their impact on the self-care of the patient with HF and, consequently, the harmful interference that these alterations may cause in the treatment and quality of life of the patient was verified. This study aimed to investigate cognitive and selfcare changes in patients with HF and to compare these changes with those in healthy participants.

\section{Materials and Methods}

This is a prospective case-control study. It was developed in the emergency room of the cardiology and medical clinic of the Hospital de Clinicas Gaspar Viana Foundation (FHCGV) in Belém, Pará, Brazil. 
To compose the case group, the following patients were considered eligible: (i) patients diagnosed with HF; (ii) patients admitted within 72 hours; (iii) patients aged $\geq 50$ years; (iv) patients without myocardial revascularization in the last month; (v) patients without signs of secondary HF and/or sepsis. All participants read and agreed to participate in the study by signing the informed consent form (ICF). Those who did not meet the inclusion criteria and those who did not agree to sign the consent form were considered ineligible.

In the control group, the following individuals participated in the study: (i) individuals aged $\geq 50$ years; (ii) individuals without evidence of cardiovascular disease, kidney disease, or other chronic degenerative diseases; (iii) individuals who showed interest in participating in the study by signing the consent form. The study did not include those who did not meet the inclusion criteria and those who did not agree to sign the informed consent form.

Data collection was performed over a period of 6 months (October 2016 to March 2017). In the case group, data were collected from 30 patients diagnosed with HF, obtained by random sampling, while in the control group, 30 participants with spontaneous demand for intuition for other causes not related to cardiovascular diseases were enrolled in the study.

Data collection was made using standardized tests such as the Montreal Cognitive Assessment (MoCA) (Nasreddine et al., 2005; Simões et al., 2008) and the Digit Symbol Substitution Test (DSST) (Rosano et al., 2016). A total of 8 cognitive domains were evaluated using the first test, while response processing speed, sustained attention, and visual and spatial skills were evaluated using the second test. Both tests were used in the case and control groups.

To assess self-care in the case group, the European Heart Failure Self-Care Behavior Scale (EHFScBS) instrument was employed, which is composed of 12 questions about the recognition of the signs and symptoms of decompensation HF and decision-making in the presence of these. The test result can be satisfactory self-care (12 points) or unsatisfactory self-care (60 points) (Jaarsma, Strömberg, Martensson \& Dracup, 2003). Alternatively, in the control group, the self-care assessment instrument was adapted by the authors, using the EHFScBS as the basic instrument and removing specific questions about HF. It also consists of 12 questions related to self-care behaviors.

Statistical analysis was performed according to the nature of the variables, with initial execution of descriptive analysis, informing the percentage values of the results of the categorical variables; in addition, means and standard deviations of numerical variables were obtained. 
The analysis of significance of categorical data was performed using chi-square or Fisher's exact statistical tests. For comparison of numerical data and normal distribution, the analysis of variance (ANOVA) was performed. The database and the tables and graphs were formatted in Microsoft Excel 2010. All analyses were performed using the Epi Info version 3.5.2 statistical software. The level of statistical significance adopted was $5 \%$ (p-value <0.05), considering a $95 \%$ confidence interval in all analyses.

This study was submitted and approved by the Research Ethics Committee - CEP of FHCGV, with CAAE: 55063716.2.0000.0016. After obtaining the approval, the study was initiated following all ethical and legal precepts, provided in Resolution No. 466/12 of the National Health Council, in all stages of the study.

\section{Results}

The case group consisted of 30 patients with HF who were treated at the cardiac emergency department of the referral center in Pará. The sample consisted mostly of male patients $(66.7 \%)$, with a mean age of 68.4 years \pm 8.04 (Table 1$)$.

Table 1: Socio-demographic characteristics of case group participants.

\begin{tabular}{|c|c|c|c|c|}
\hline VARIABLES & $\mathbf{N}(\mathbf{3 0})$ & $\%$ & AVERAGE & DP \\
\hline \multicolumn{5}{|l|}{ Sex } \\
\hline Male & 20 & 66,7 & - & - \\
\hline Feminine & 10 & 33,3 & - & - \\
\hline \multicolumn{5}{|l|}{ Age } \\
\hline $50-59$ & 4 & 13,3 & \multirow{4}{*}{68,4} & \multirow{4}{*}{8,04} \\
\hline $60-69$ & 13 & 43,3 & & \\
\hline $70-79$ & 8 & 26,6 & & \\
\hline$\geq 80$ & 5 & 16,6 & & \\
\hline
\end{tabular}

\section{Provenance}

Belém 


\section{Breed}

White

Black

Yellow

Parda

$4 \quad 13,3$

$16 \quad 53,3$

Indigenous

I couldn't inform

26,6

\section{Family income}

Less than 1 minimum wage

1136,6

Greater than 1 and less than 21

$$
14 \quad 46,6
$$

Greater than 2 and less than or equal to 5

$4 \quad 13,3$

Greater than 5 and less than or equal to 10

Greater than 10 minimum wages

$1 \quad 3,3$

\section{Schooling}

Not literate

Incomplete Elementary

$6 \quad 20$

Complete Elementary

$14 \quad 46,6$

Incomplete high school

$1 \quad 3,3$

Complete high school

26,6

$4 \quad 13,3$

Incomplete higher education

$1 \quad 3,3$

Higher Education

$1 \quad 3,3$


Source: Research Data, 2019.

The largest proportion came from the capital of Belém; self-declared brown, making up $54.3 \%$ of the total; presenting mostly income from 1 to 2 minimum wages; and $46.7 \%$ of patients did not complete elementary school.

Impairments in three cognitive domains were identified in this study: memory, processing speed, and executive function. When comparing the cognitive impairment of patients with HF with that of healthy participants, it was noticed that the case group presented the highest incidence of cognitive impairment, with statistical significance in all domains (Table 2).

Table 2: Comparison of cognitive tests between the group of patients with HF (case) and the healthy group (control), treated at FHCGV, in 2017, Belém, Pará.

\begin{tabular}{lccc}
\hline $\begin{array}{c}\text { COGNITIVE TEST }- \\
\text { LOSSES }\end{array}$ & $\begin{array}{c}\text { GROUP CONTROL }(\mathbf{N}=30) \\
(\%)\end{array}$ & $\begin{array}{c}\text { CASE GROUP }(\mathbf{N}=\mathbf{3 0}) \\
(\%)\end{array}$ & $\begin{array}{c}\text { p- } \\
\text { value }\end{array}$ \\
\hline Processing Speed & $17(56,6 \%)$ & $28(93,3 \%)$ & $\mathbf{0 , 0 0 2 *}$ \\
Memory & $14(46,6 \%)$ & $23(76,6 \%)$ & $\mathbf{0 , 0 3 *}$ \\
Executive Function & $10(33,3 \%)$ & $19(63,3 \%)$ & $\mathbf{0 , 0 3 8}$ \\
\hline
\end{tabular}

*Qui-quadrado corrigido de Yates

Source: Research Data, 2019.

Processing speed was the most affected domain, being identified in $93.3 \%$ of $\mathrm{HF}$ patients and in 56.6\% of the participants in the control group, followed by memory impairment, withthe highest prevalence being in the case group in $76.6 \%$ of the patients and with prevalence in the control group in $46.6 \%$ of the participants.

For self-care assessment, EHFScBS was used, with the results obtained from the participants' assessment, the arithmetic mean and standard deviation were calculated (Table 3). It is noteworthy that the present study identified a minimum score of 19 points and a maximum of 49 points. 
Research, Society and Development, v. 9, n. 6, e98963321, 2020

(CC BY 4.0) | ISSN 2525-3409 | DOI: http://dx.doi.org/10.33448/rsd-v9i6.3321

Table 3: Comparison of self-care performance between healthy participants and HF patients treated at FHCGV in 2017, Belém, Pará.

GROUP CONTROL

SELF-CARE

\section{CASE GROUP}

$(\mathrm{N}=30)(\%) \quad$ p-value

(Mean and standard deviation)

\begin{tabular}{cccc}
\hline POINTS & $31,8 \pm 8,2$ & $29,7 \pm 6,9$ & $0,30^{*}$ \\
\hline
\end{tabular}

*ANOVA

Source: Research Data, 2019.

Regarding the self-care score obtained using the EHFScBS in the case and control groups, it was noticed that patients with HF had slightly better self-care, with a mean score of $29.7 \pm 6.9$, while healthy participants obtained a mean score of $31.8 \pm 8.2$, both with regular self-care classification.

When correlating cognitive impairment with the sociodemographic profile of HF patients, it was observed that female patients had greater impairment in memory, processing speed, and executive function domains, without statistical significance, with an average of 2.5 \pm 0.7 (Table 4). 
(CC BY 4.0) | ISSN 2525-3409 | DOI: http://dx.doi.org/10.33448/rsd-v9i6.3321

Table 4: Correlation between the sociodemographic profile and cognitive and selfcare changes of patients with HF in the case group treated at FHCGV in 2017, Belém, Pará.

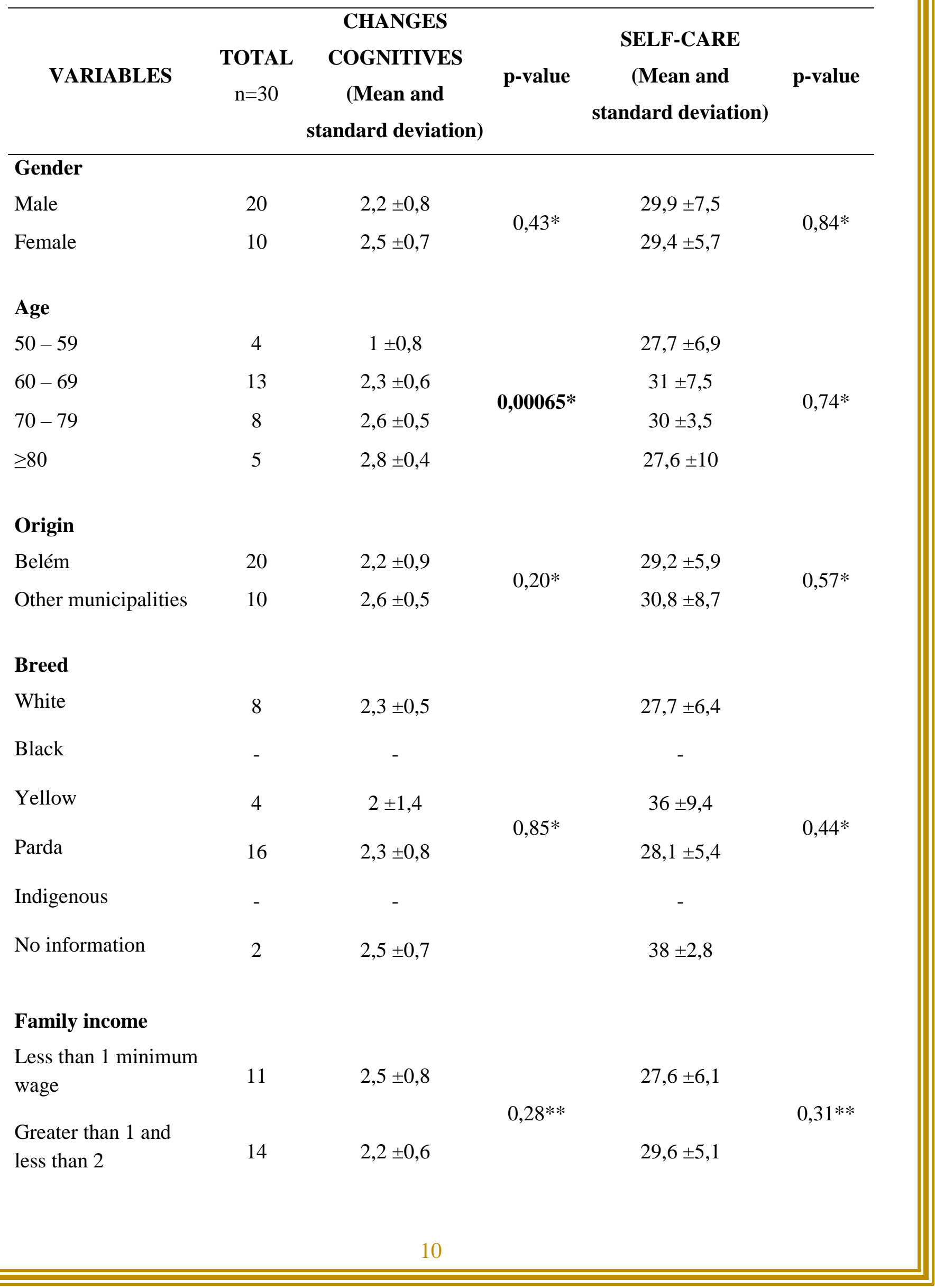


Greater than 2 and

less than or equal to 5

4

$1,7 \pm 1,2$

$36,7 \pm 11,6$

Greater than 5 and

less than or equal to

10

Greater than 10

minimum wages

\section{Education}

Not literate

6

$2,6 \pm 0,5$

$29 \pm 7,2$

Incomplete

elementary school

14

$2,5 \pm 0,6$

$27 \pm 4,7$

Complete elementary

school

Incomplete high

school

2

$2 \pm 1,4$

$32 \pm 4,2$

$0,30 * *$

$0,40 * *$

Complete high school

4

$2,5 \pm 0,5$

$33,5 \pm 12,2$

Incomplete higher

education

Complete higher

education

No information

1

*ANOVA

**Kruskal-Wallis

Source: Research Data, 2019.

Additionally, age over 70 years was found to be associated with higher cognitive impairment $(\mathrm{p}=0.00065)$. Followed by patients from other municipalities with an average of $2.6 \pm 0.5$, with an income of less than 1 minimum wage with an average of $2.5 \pm 0.8$ and patients who declared themselves not literate with an average of $2.6 \pm 0.5$, although not statistically significant.

There was no significant relationship between sociodemographic and self-care profiles, although self-care in the case group was slightly better than that in the control group. It is noteworthy that the best HF patient scores through the EHFScBS were obtained by 
female patients with a mean score of $29.4 \pm 5.7$; patients included in the age group $\geq 80$ with a mean of $27.6 \pm 10$; patients from the municipality of Belém with an average of $29.2 \pm 5.9$; white patients $(27.7 \pm 6.4)$; patients with family income less than one minimum wage with an average of $27.6 \pm 6.1$; and patients with incomplete elementary schooling (27 \pm 4.7 ).

\section{Discussion}

Regarding the participants' gender, the present study corroborates the findings of the study conducted by Sousa et al. (2018), according to which $61 \%$ of the patients with HF were male. The mean age identified in this study was $68.4 \pm 8.04$ years, similar to the national standard of $64.1 \pm 15.9$ years (Albuquerque et al., 2015). There was a predominance of brown race, followed by white and then black; such data are in line with those obtained by Medeiros \& Medeiros (2017), who found values of $63.2 \%, 28.1 \%$, and $8.8 \%$ for brown, white, and black populations, respectively.

Margoto, Colombo \& Gallani (2009) demonstrated in their study, conducted in a university hospital in the interior of São Paulo, the prevalence of HF cases among males (54.1\%), with an average age of 58 years, low level of education, and informed average monthly of 1 to 2 minimum wages, showing similarity with the data found in our study. The prevalence of HF in males was also identified by Nascimento (2012), in a study carried out at the clinical hospital of the Medical School of São Paulo, in which 120 patients participated in the study, of which $65 \%$ were male.

Compared to the control group, the case group had a higher number of participants with cognitive impairment, all with statistical significance. These data are in line with those of international studies, which point out that cognitive impairments in patients with HF in the domains related to memory, attention, psychomotor speed, and executive function may affect the self-care decision-making capacity and the ability of the patient to comply with treatment and to recognize and manage worsening symptoms (Ferreira et al., 2015; Riegel, Lee, \& Dickson 2011).

In the study by Sauvé, Lewis, Blanklenbiller, Rickabaugh \& Pressler (2009), the authors recruited $50 \mathrm{HF}$ patients, who were compared with 50 control/healthy individuals, and they found that patients had significantly lower scores than controls, and this was evaluated using specific tests. This corroborates the findings of our study, in which there was statistical 
significance when comparing cognitive changes between the case and control groups in the three domains evaluated.

Studies have demonstrated that memory impairment in HF patients may influence the effective performance of self-care in several ways. This memory impairment may impede learning and retention of information necessary to maintain disease stability, such as remembering the dosage and timing of medications or remembering to monitor weight daily. These patients may have difficulty recognizing the main symptoms of disease decompensation and taking early actions that prevent readmission (Hajduk et al., 2013; Kim \& Shin, 2012). In the present study, there was greater impairment in processing speed in individuals with HF, which may influence rapid decision-making, symptom identification, and seeking medical care, impairing self-care.

Studies conducted by Parissis et al. (2013) and Carvalho (2014) show a prevalence of cognitive impairment in female HF patients, as they present more negative feelings, loss of hope, reduced perception of family and social support, and, especially, development of depressive conditions, which may be related to the high rates of cognitive impairment. Although done discreetly, the present study revealed a prevalence of cognitive impairment in females, but without statistical significance.

Although the case group presented alterations in all the evaluated domains of cognition, such data do not indicate that this is irreversible damage. Studies show that most cognitive impairments are reversible and point out that aerobic physical activity can contribute to the improvement of cognition, especially the domain of executive functions, and to improved quality of life of these patients. Thus, it is essential that physical activity is included as an element of treatment for patients (Galioto, Fedor \& Gunstad, 2015; Rêgo, Cabral \& Fontes, 2018).

In the self-care assessment, the score obtained in the case group was slightly lower than that in the control group, thus indicating better self-care in individuals with HF; however, there was no statistical significance. In the study by Sousa et al. (2018) at a cardiology outpatient clinic in João Pessoa, Paraíba, Brazil, 100 patients with HF were evaluated. With regard to self-care analysis, similar data were obtained with a mean score of $35.17 \pm 7.87$, ranging from 15 to 54 points. 
It is believed that obtaining better self-care scores in the case group is related to patients' knowledge about their disease and the factors associated with it. Studies indicate that part of the success of the HF treatment is associated with patients' knowledge of its pathology, contributing to an adequate perception of their health status (Bonin et al., 2016).

In a study by Rockwell \& Riegel (2001) on 209 HF patients in six American hospitals, seven variables were analyzed and only two were predictors of self-care: education ( $\mathrm{p}=$ $0.009)$ and symptom severity $(\mathrm{p}=0.046)$; thus, the study points out that understanding and performing adequate self-care reduces the risk of worsening of the disease and, consequently, of readmissions and deaths of patients with HF.

In contrast, the data obtained here contradict the findings in other national studies that show that the higher the educational level, the lower the scores, resulting in better self-care. In the case group, participants with lower educational level had lower scores than participants with higher education level (Conceição, Santos, Santos \& Cruz, 2015; Ferreira et al., 2015; Rockwell \& Riegel 2014; Sousa et al., 2018).

A study by Hajduk et al. (2013) shows that cognitive impairment has been identified in older patients with low educational attainment.

The findings of this study are similar to ours, where we noticed the difficulties the study population faced when performing cognitive tests, which may be somewhat impaired by the lack of knowledge and understanding due to the factors of age and education, and this interferes with the test results. This indicates that the impairment of cognitive factors may not be linked only to HF.

\section{Final Considerations}

In this study, impairment was observed in three cognitive domains, with processing speed being the most impaired domain. There was a significant correlation between cognitive changes and age. However, self-care was similar for all participants.

There was a significant correlation between case and control groups when comparing cognitive changes, however, when self-care was evaluated, there was no significant relationship between the groups. Given these results, it is clear that cognitive impairment is not shown to have an isolated influence on self-care, considering that it presented differently. However, the cognitive changes of the patients in the case group showed greater impairment. 
Research, Society and Development, v. 9, n. 6, e98963321, 2020

(CC BY 4.0) | ISSN 2525-3409 | DOI: http://dx.doi.org/10.33448/rsd-v9i6.3321

The present results helped in the construction and development of multidisciplinary team interventions that seek to promote and improve self-care in patients with $\mathrm{HF}$, taking into account their profile and the degree of cognitive impairment, an aggravating factor identified among most patients affected by HF. We emphasize the need for further studies that show ways to improve self-care and prevent cognitive changes in patients with HF, aiming at a better quality of life.

A limitation of this study is the use of self-reported self-care scales, in addition to the cross-sectional design of the study, which makes it impossible to assess long-term behavior and interference of casualties and factors that affect self-care.

Cognition is a key factor in self-care, treatment adherence and health maintenance in the elderly population in chronic conditions. Therefore, it is suggested here additional studies that can reinforce the importance of this individual before public health policies and his role in the readjustment of lifestyle, especially in limiting conditions such as heart failure.

\section{Conflict of interest}

The authors declare that they have no conflict of interest.

\section{References}

Albuquerque, D.C., Souza Neto, J.D., Bacal, F., Rohde, L.E.P., Pereira, S.B., Berwanger, O. \& Almeida, D.R. (2015). I Brazilian Registry of Heart Failure - Clinical Aspects, Care Quality and Hospital Outcomes. Arq. Bras. Cardiol., 104: 433-42. DOI: 10.5935/abc.20150031.

Boisvert, S., Proulx-Belhumeur, A., Gonçalve, N., Francoeur, J. \& Gallani, M.C. (2015). An integrative literature review on nursing interventions aimed at increasing self-care among heart failure patients. Rev. Latino-Am. Nursing, 23 (4): 753-68. DOI: 10.1590/01041169.0370.2612.

Bonin, C.B., Saints, R.Z, Erkmann, N., Souza, V.F., Assisi, A.V. \& Benetti, M. (2016). Knowledge About Heart Failure in Participants and Non-Participants Cardiac 
Research, Society and Development, v. 9, n. 6, e98963321, 2020

(CC BY 4.0) | ISSN 2525-3409 | DOI: http://dx.doi.org/10.33448/rsd-v9i6.3321

Rehabilitation. International Journal of Cardiovascular Sciences, 29 (6): 453-459. DOI:

$10.5935 / 2359-4802.20170001$.

Brazil. Ministry of Health. (2019a). Mortality Information System (SIM), 1996-2017. Brasilia: Ministry of Health. Available at:

http://tabnet.datasus.gov.br/cgi/deftohtm.exe?sim/cnv/obt10uf.def.

Brazil. Ministry of Health. (2019b). SUS Hospital Information System (SIH/SUS). Brasilia: Ministry of Health. Available at:

http://tabnet.datasus.gov.br/cgi/deftohtm.exe?sih/cnv/nibr.def.

Carvalho, M.F.O. (2014). Evidencia de validade do millon behavioral medicine diagnostico na avaliação de aderência terapêutica em pacientes com insuficiência cardíaca crônica.

Natal Rio Grande do Norte. Disponível em:

https://repositorio.ufrn.br/jspui/handle/123456789/19463.

Conceição, A.P., Santos, M.A., Santos, B. \& Cruz, D.A.L.M. (2015). Self-care of patients with heart failure1. Rev. Latino-Am. Nursing, 23 (4): 578-86. DOI: 10.1590/01041169.0288.2591.

Coordinating Committee of the Heart Failure Directive (CCDIC). (2018). Brazilian Guideline for Chronic and Acute Heart Failure. Arq. Bras. Cardiol., 111 (3): 436-539. DOI: $10.5935 / \mathrm{abc} .20180190$.

Ferreira, V.M.P., Silva, L.N., Furuya, R.K., Schmidt, A., Rossi, L.A \& Dantas, R.A.S. (2015). Self-care, sense of coherence and depression in patients hospitalized for decompensated heart failure. Rev Esc Enferm USP, 49 (3): 388-394. DOI: 10.1590/S0080-623420150000300005.

Galioto R., Fedor A.F. \& Gunstad J. (2015). Possible neurocognitive benefits of exercise in persons with heart failure. Eur Rev Aging Phys Act, 12 (6): 1-7. DOI:

https://doi.org/10.1186/s11556-015-0151-x. 
Hajduk, A.M., Lemon, S.C., McManus, D.D., Lessard, D.M., Gurwitz, J.H., Spencer, F.A., Goldberg, R.J. \& Saczynski, J.S. (2013). Cognitive impairment and self-care in heart failure. Clin Epidemiol, 5: 407-16. DOI: 10.2147/CLEP.S44560.

Jaarsma, T., Strömberg, A., Mårtensson, J. \& Dracup, K. (2003). Development and testing of the European Heart Failure Self-Care Behavior Scale. European Journal of Heart Failure, 5: 363-370. DOI: 10.1016/S1388-9842(02)00253-2.

Kim, J.S. \& Shin, J.H. (2012). Cognitive Function and Self-Care in Patients with Heart Failure: A Pilot Study from Korean Patients. Perspectives in Nursing Science, 9 (1): 45-50. Available at: http://hdl.handle.net/10371/86555.

Margoto, G., Colombo, R.C.R. \& Gallani, M.C.B.J. (2009). Clinical and psychosocial features of heart failure patients admitted for clinical decompensation. Rev. Esc. Sick USP, 43 (1): 44-53. DOI: http://dx.doi.org/10.1590/S0080-62342009000100006.

Medeiros, J. \& Medeiros, C.A. (2017). Self-care assessment in patients with heart failure. Cogitare Enferm, (22) 3: e51082. DOI: http://dx.doi.org/10.5380/ce.v22i3.510.

Nascimento, H.R. (2012). Self-care in heart failure: comparative study between patients of specialized clinic and emergency room. University of Sao Paulo. Nursing school. Available at: https://www.eses.usp.br/eses/disponiveis/7/7139/tde-22082012-153318/publico/01.pdf.

Nasreddine, Z., Phillips, N.A., Bédirian, V., Charbonneau, S., Whitehead, V., Collin, I., Cummings, J.L. \& Chertkow, H. (2005). The Montreal Cognitive Assessment, MoCA: A brief screening tool for Mild Cognitive Impairment. American Geriatrics Society, 53, 695-699.

Parissis, JT, Mantziari, L., Kaldoglou, N., Ikonomidis, I., Nikolaou, M., Mebazaa, A., Altenberger, J., Delgado, J., Vilas-Boas, F., Paraskevaidis, I. ,Anastasiou-Nana, M. \& Follath, F. (2013). Gender-related differences in patients with acute heart failure: management and predictors of in-hospital mortality. Int J Cardiol, 168 (1): 185-9. DOI:

101016/j.ijcard.2012.09.096. 
Rêgo, M.L.M., Cabral, D.A.R. \& Fontes, E.B. (2018). Cognitive Deficit in Heart Failure and the Benefits of Aerobic Physical Activity. Arq. Bras. Cardiol., 110 (1): 91-94. DOI: http://dx.doi.org/10.5935/abc.20180002.

Riegel, B., Lee, C. \& Dickson, V.V. (2011). Self-care in patients with chronic heart failure. Nat Rev Cardiol, 8 (11): 644-54. DOI: 10.1038/nrcardio.2011.95.

Rockwell, J.M. \& Riegel, B. (2001). Predictors of self-care in persons with heart failure. Heart Lung, 30 (1): 18-25. DOI: 10.1067 / mhl.2001.112503.

Rosano, C., Perera, S., Inzitari, M., Newman, A.B., Longstreth, W. T. \& Studenski, S. (2016). Digit Symbol Substitution test and future clinical and subclinical disorders of cognition, mobility and mood in older adults. Age and Ageing, 45 (5): 688-695. DOI: https://doi.org/10.1093/ageing/afw116.

Sauvé, M., Lewis, W.R., Blanklenbiller, M., Rickabaugh, B. \& Pressler, S.J. (2009). Cognitive impairments in chronic heart failure: a case controlled study. J Card Fail, 15 (1): 110. DOI: 10.1016/j.cardfail.2008.08.007.

Simões, M.R., Freitas, S., Santana, I., Firmino, H., Martins, C., Nasreddine, Z. \& Vilar, M. (2008). Montreal Cognitive Assessment (MoCA): Portuguese final version. Psychological Assessment Service, Faculty of Psychology and Educational Sciences, University of Coimbra. Coimbra.

Sousa, M.S., Almeida, T.C.F., Gouveia, B.L.A., Marta, F.C., Brito, F.M. \& Oliveira, S.H.S. (2018). Relationship between self-care and social and clinical conditions of patients with heart failure. Rev. Rene, 19: e33062. DOI: https://doi.org/10.15253/2175-6783.20181933062.

Uchmanowicz, I. Polańska, J.,Mazur, G. \& Froelicher, E.S. (2017). Cognitive deficits and self-care behaviors in elderly adults with heart failure. Clinical Interventions in Aging, 12, 1565-1572. DOI: https://doi.org/10.2147/CIA.S140309. 
Adriana de Oliveira Lameira Veríssimo - 20\%

Juniel Pereira Honorato - 10\%

Sílvio Douglas Medeiros Costa - 10\%

João Victor Moura Garcia - 20\%

Isis Jaspe Reis da Silva - 10\%

Stanley Soares Xavier - 10\%

Aline Maria Pereira Cruz Ramos - 10\%

Milene Gouvêa Tyll - 10\% 